\title{
Original Research \\ Decontamination of 4-Chloro-2-Nitrophenol from Aqueous Solution by Graphene Adsorption: Equilibrium, Kinetic, and Thermodynamic Studies
}

\author{
Ali Mehrizad ${ }^{1 *}$, Parvin Gharbani ${ }^{2}$ \\ 'Department of Chemistry, College of Sciences, East Azarbaijan Science and Research Branch, \\ Islamic Azad University, Tabriz, Iran \\ ${ }^{2}$ Department of Chemistry, College of Sciences, Ahar Branch, Islamic Azad University, Ahar, Iran
}

Received: 24 March 2014

Accepted: 30 May 2014

\begin{abstract}
4-Chloro-2-nitrophenol (4C2NP) is an important chemical widely used in the pharmaceuticals, herbicide, and pesticide industries. The ability of graphene to remove $4 \mathrm{C} 2 \mathrm{NP}$ from aqueous solutions was performed as a function of contact time, amounts of adsorbent, $\mathrm{pH}$, initial 4C2NP concentrations, and temperatures using a batch technique. Based on the results, the amount of 4C2NP adsorption increased with increasing initial concentration, whereas the alkaline $\mathrm{pH}$ range, higher graphene dosage, and higher temperature were unfavorable. Non-linear regression methods suggest that the isotherm data can be well described by the Freundlich isotherm equation. The adsorption kinetic data were analyzed using the non-linear rate equations of pseudo-first and pseudo-second order. It was found that the pseudo-second-order kinetic model was the most appropriate model, describing the adsorption kinetics. The observed changes in the standard Gibbs free energy $\left(\Delta G^{\circ}\right)$, standard enthalpy $\left(\Delta H^{\circ}\right)$, and standard entropy $\left(\Delta S^{\circ}\right)$ show that the adsorption of $4 \mathrm{C} 2 \mathrm{NP}$ by graphene is feasible, spontaneous, and exothermic in the temperature range 298-328 K.
\end{abstract}

Keywords: adsorption, 4-chloro-2-nitrophenol, graphene

\section{Introduction}

Phenol and its compounds are one of the major materials commonly used in the petrochemical, coking, coal refining, chemical, and pharmaceutical industries $[1,2]$. The harmful effects due to the presence of phenols in industrial wastewaters have been confirmed [3,4]. Thus, development of suitable methods for the decontamination of phenols is necessary. Research has studied the removal of phenol from aqueous solutions, including advanced oxidation processes [5, 6], biological degradation [7, 8], ozonation [9, 10], adsorption [11-14], etc. Among these methods, adsorption has been developed as a simple and cheap method to

*e-mail: mehrizad@iauasrb.ac.ir treat phenolic compounds. Various adsorbents such as bentonite [15], sawdust [16], activated carbon [17], nano-titanium dioxide [18], and carbon nanotubes [19] have been tested for adsorption of phenol and its compounds from aqueous solutions. Among them, carbon materials show significant adsorption yields. This may be because of their large surface area and good distribution of pore size. Therefore, using new carbonaceous materials as adsorbents is interesting for scientists. An example of a new carbonaceous material is graphene, whose atoms are arranged in a 2D honeycomb structure [20]. As literature results show, graphene has a high adsorption capacity for removal of aqueous pollutants [21-25].

In the present study, the potential application of graphene for 4-chloro-2-nitrophenol (4C2NP) adsorption 
from aqueous solutions was investigated. Adsorption kinetics, isotherms, and thermodynamics were deduced from the experimental results.

\section{Materials and Methods}

\section{Materials}

Graphene nanopowder was supplied by Supermarket, USA. Average particle (lateral) size, average flake thickness, and specific surface area of nanopowders were about 10 microns, $1 \mathrm{~nm}$ (less than 3 monolayers), and $510 \mathrm{~m}^{2} / \mathrm{g}$, respectively. $4 \mathrm{C} 2 \mathrm{NP}\left(\mathrm{C}_{6} \mathrm{H}_{4} \mathrm{ClNO}_{3}, \mathrm{M}_{\mathrm{w}}=173.56 \mathrm{~g} / \mathrm{mol}\right)$ was purchased from Fluka, Germany.

\section{Adsorption Experiments}

Batch adsorption experiments of 4C2NP onto graphene were carried out to obtain equilibrium data. A stock solution $(1000 \mathrm{mg} / \mathrm{L})$ was prepared by dissolving 4C2NP in ethanol and then diluting with distilled water $(\mathrm{pH}$ of this solution was almost 4.5 ). The effects of main parameters such as contact time, graphene doses (0.2-0.8 g/L), pH (3-10), initial 4C2NP concentrations $(2-10 \mathrm{mg} / \mathrm{L})$, and temperatures (298-328 K) were studied. Solution $\mathrm{pH}$ was adjusted by $\mathrm{HCl}$ or $\mathrm{NaOH}$. Experiments were down in an Erlenmeyer flask on a hot plate stirrer (300 rpm) by adding $250 \mathrm{~mL}$ of $4 \mathrm{C} 2 \mathrm{NP}$ solution and the desired amount of graphene. At predetermined time intervals, samples were drawn and were filtered using $0.22 \mu \mathrm{m}$ membrane filters. The concentration of $4 \mathrm{C} 2 \mathrm{NP}$ in the filtrate was measured by a UV-Vis spectrophotometer (SPEKOL 1500, analytikjena Co., Germany) at maximum wavelength $\left(\lambda_{\max }=219 \mathrm{~nm}\right.$ for acidic pHs or $234 \mathrm{~nm}$ for neutral and alkaline $\mathrm{pHs}$ ).

The amounts of adsorbed $4 \mathrm{C} 2 \mathrm{NP}$ at various and equilibrium times were obtained from equations (1) and (2), respectively:

$$
\begin{aligned}
& q_{t}=\frac{\left(C_{0}-C_{t}\right)}{m} \times V \\
& q_{e}=\frac{\left(C_{0}-C_{e}\right)}{m} \times V
\end{aligned}
$$

...where $C_{0}, C_{t}$, and $C_{e}$ represent the initial various time $t$ and equilibrium concentrations of $4 \mathrm{C} 2 \mathrm{NP}(\mathrm{mg} / \mathrm{L})$, respectively. $V$ is the solution volume (L) and $m$ is the adsorbent mass $(\mathrm{g})$.

Zeta potential of graphene was measured by a Dynamic light scattering (DLS) instrument (Nanotrac Wave, Microtrac Co.).

\section{Results and Discussion}

\section{Effect of Contact Time and Graphene Dosage}

The amount of 4C2NP adsorption onto graphene versus contact time and adsorbent dose is illustrated in Fig. 1.
The adsorption capacity of graphene decreased with increasing dosage. This decline can be due to the aggregation of graphene and an increase in diffusion path length of 4C2NP molecules [26]. As shown in Fig. 1, the adsorption of 4C2NP by graphene increased rapidly in the first $10 \mathrm{~min}$ and then achieved equilibrium gradually at about $60 \mathrm{~min}$. Thus, one hour was selected as the contact time. The fast adsorption at the initial period can be related to the special one-atom-thick layered structure of graphene, which makes 4C2NP contact immediately with the active vacant sites on the graphene surface [27].

\section{Effect of $\mathrm{pH}$}

The $\mathrm{pH}$ of solution affects the ionization of adsorbate and the adsorbent's surface charge [28]. As shown in the zeta potential analysis (Fig. 2), the $\mathrm{pH}$ of the zero point of charge $\left(\mathrm{pH}_{\mathrm{zpc}}\right)$ for graphene is 6 . This indicated that graphene sheets possess a positive charge at $\mathrm{pH}<6$ and negative charge at $\mathrm{pH}>6$. The experimental results (Fig. 3) demonstrate that the adsorption of $4 \mathrm{C} 2 \mathrm{NP}$ by graphene decreases with increases in $\mathrm{pH}$. The decrease in adsorption until $\mathrm{pH}=7$ is gradual, and then it drops significantly at $\mathrm{pH}>7$. In fact, there is not a repulsive electrostatic interaction between the non-ionized 4C2NP and graphene surfaces at $\mathrm{pH}<7\left(4 \mathrm{C} 2 \mathrm{NP}, \mathrm{pK}_{\mathrm{a}}=6.46,25^{\circ} \mathrm{C}\right)$ and the adsorption is higher. As $\mathrm{pH}>\mathrm{pK}_{\mathrm{a}}, 4 \mathrm{C} 2 \mathrm{NP}$ dissociates and forms

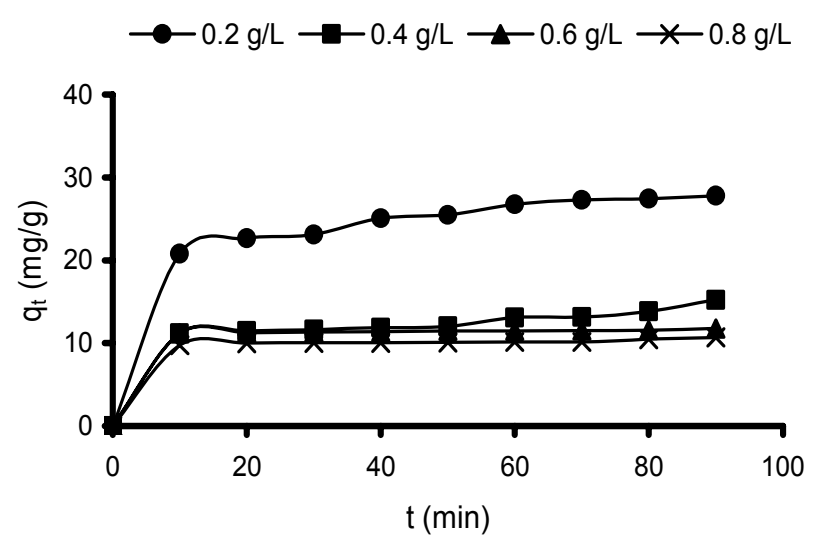

Fig. 1. Effect of contact time and graphene dosage $\left([4 \mathrm{C} 2 \mathrm{NP}]_{0}=10 \mathrm{mg} / \mathrm{L}, \mathrm{pH}=4.5, \mathrm{~T}=298 \mathrm{~K}\right)$.

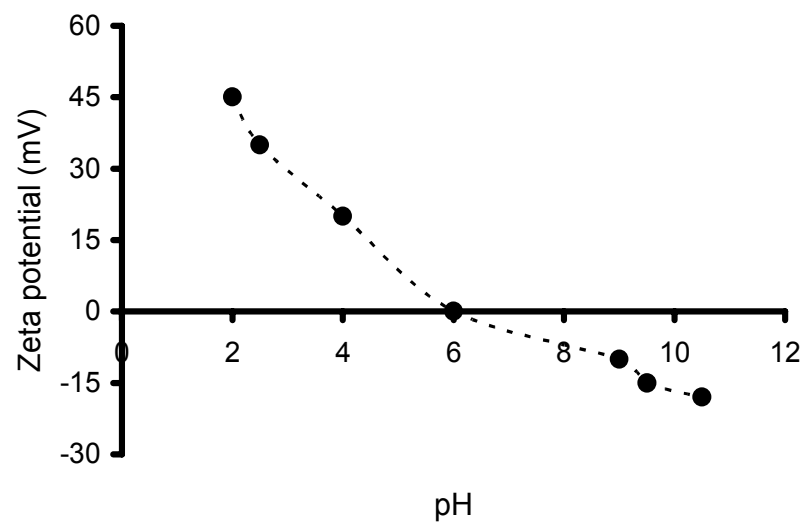

Fig. 2. Zeta potential curve versus $\mathrm{pH}$ of graphene. 


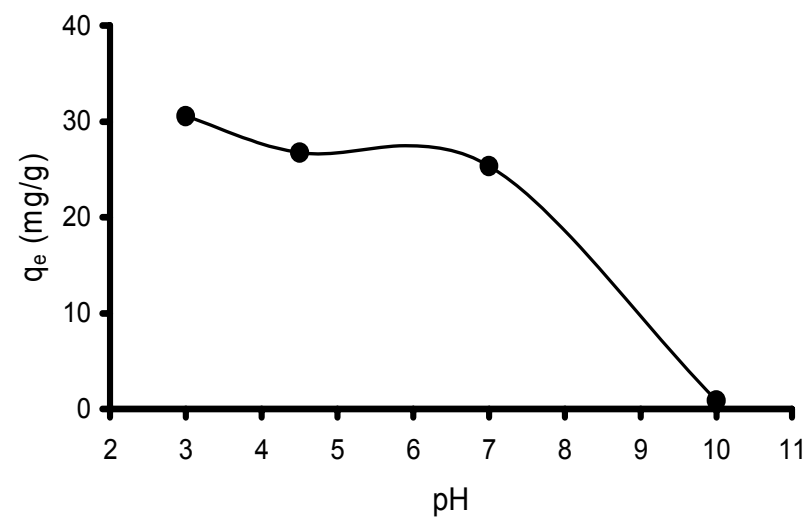

Fig. 3. Effect of $\mathrm{pH}\left([4 \mathrm{C} 2 \mathrm{NP}]_{0}=10 \mathrm{mg} / \mathrm{L}\right.$, graphene dose $=0.2$ $\mathrm{g} / \mathrm{L}, \mathrm{T}=298 \mathrm{~K})$.

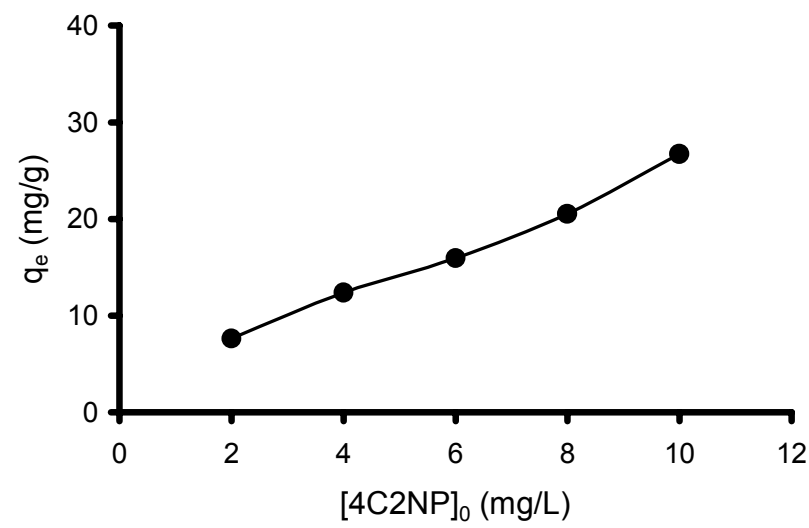

Fig. 4. Effect of initial concentration (graphene dose $=0.2 \mathrm{~g} / \mathrm{L}$, $\mathrm{pH}=4.5, \mathrm{~T}=298 \mathrm{~K}$ ).

$\mathrm{C}_{6} \mathrm{H}_{3} \mathrm{ClNO}_{3}^{-}$anions, while graphene's surface contains a negative charge, the repulsive electrostatic interactions cause a decrease in sorption. Such observations were also reported by other researchers [29].

\section{Effect of Initial Concentration}

As shown in Fig. 4, by increasing the initial 4C2NP concentration, adsorption of $4 \mathrm{C} 2 \mathrm{NP}$ onto graphene was increased. In fact, the initial concentration can provide a driving force to overcome the resistances to the mass trans-

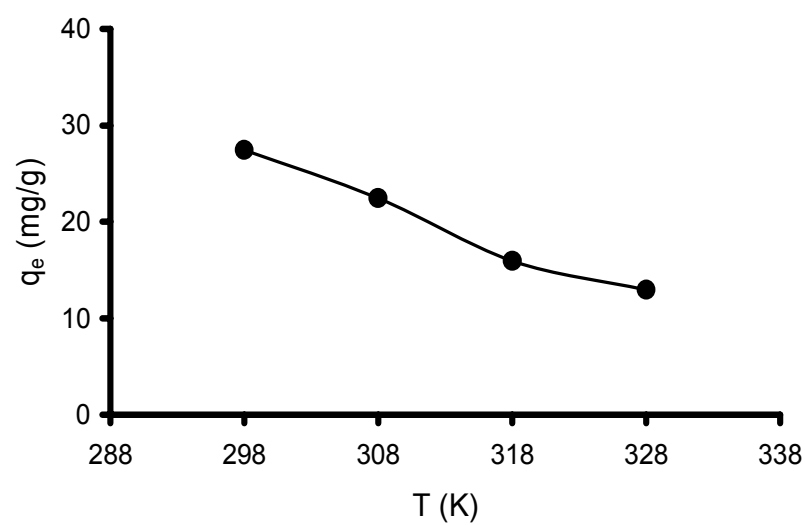

Fig. 5. Effect of temperature $\left([4 \mathrm{C} 2 \mathrm{NP}]_{0}=10 \mathrm{mg} / \mathrm{L}\right.$, graphene dose $=0.2 \mathrm{~g} / \mathrm{L}, \mathrm{pH}=4.5$ ). fer of $4 \mathrm{C} 2 \mathrm{NP}$ from aqueous to solid phase. In addition, this may be due to higher interaction between 4C2NP and graphene [30].

\section{Effect of Temperature}

To evaluation the temperature effect on the adsorption process, four different temperatures were selected (298 to $328 \mathrm{~K})$. Fig. 5 shows that the 4C2NP adsorption by graphene was decreased by increasing the temperature from 298 to $328 \mathrm{~K}$. It may be due to this fact that at low temperatures, more active sites are available [31].

\section{Adsorption Isotherm Studies}

Isotherm studies were conducted with various initial concentrations of $4 \mathrm{C} 2 \mathrm{NP}(2-10 \mathrm{mg} / \mathrm{L})$, with $0.2 \mathrm{~g} / \mathrm{L}$ of garphene at $25^{\circ} \mathrm{C}$ and $\mathrm{pH}=4.5$. Non-linear forms of Langmuir, Freundlich, and Temkin models were fitted to adsorption equilibrium data (equations 3-5, respectively):

$$
\begin{gathered}
q_{e}=\frac{q_{m} K_{L} C_{e}}{1+K_{L} C_{e}} \\
q_{e}=K_{F} C_{e}^{\frac{1}{n}} \\
q_{e}=B_{1} \operatorname{Ln}\left(K_{T} C_{e}\right)
\end{gathered}
$$

...where $q_{m}$ is the maximum amount of adsorption $(\mathrm{mg} / \mathrm{g})$ and $K_{L}$ is the affinity constant $(\mathrm{L} / \mathrm{mg}) . K_{F}\left[(\mathrm{mg} / \mathrm{g}) \cdot(\mathrm{L} / \mathrm{mg})^{1 / n}\right]$ and $n$ are the Freundlich constants indicating adsorption capacity and adsorption strength, respectively. $K_{T}(\mathrm{~L} / \mathrm{g})$ and $B_{1}$ are the Temkin model constant [32-34].

The curves of experimental data and results obtained from different models are shown in Fig. 6.

Polymath software (version 6.10) was used to determine the isotherm constants. We have used correlation coefficient $\left(\mathrm{R}^{2}\right)$ and adjusted correlation coefficient $\left(\mathrm{R}_{\mathrm{adj}}^{2}\right)$ parameters to predict which model correctly represents the data. If $\mathrm{R}^{2}$ value was close to one and also close to $\mathrm{R}_{\text {adj. }}^{2}$ it could be concluded that the regression model is correct [35]. Root mean square error and average relative error

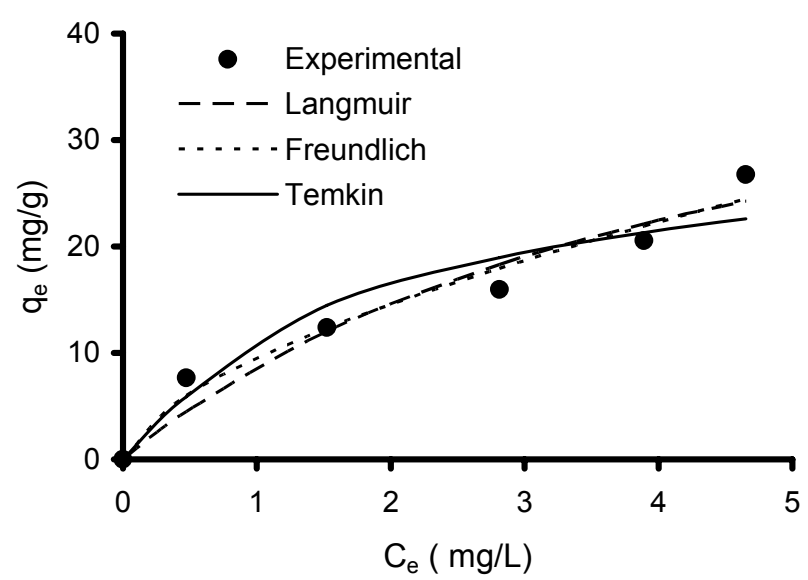

Fig. 6. Plots of non-linear adsorption isotherm models $\left([4 \mathrm{C} 2 \mathrm{NP}]_{0}=2-10 \mathrm{mg} / \mathrm{L}\right.$, graphene dose $\left.=0.2 \mathrm{~g} / \mathrm{L}, \mathrm{pH}=4.5, \mathrm{~T}=298 \mathrm{~K}\right)$. 
Table 1. Isotherm parameters and error deviation data for 4C2NP adsorption onto graphene.

\begin{tabular}{|c|c|c|c|c|c|c|}
\hline Model & $\mathrm{R}^{2}$ & $\mathrm{R}_{\text {adj. }}^{2}$ & $R m s$ & $A R E$ & Parameters & Values \\
\hline \multirow{3}{*}{ Langmuir } & 0.945 & 0.932 & 0.820 & 15.16 & $q_{m}(\mathrm{mg} / \mathrm{g})$ & 48.346 \\
\cline { 2 - 7 } & & & & & $K_{L}(\mathrm{~L} / \mathrm{mg})$ & 0.216 \\
\hline \multirow{2}{*}{ Freundlich } & 0.969 & 0.961 & 0.619 & 9.96 & $K_{F}\left[(\mathrm{mg} / \mathrm{g}) \cdot(\mathrm{L} / \mathrm{mg})^{1 / n}\right]$ & 9.495 \\
\cline { 2 - 8 } & & & & & $n$ & 1.624 \\
\hline \multirow{2}{*}{ Temkin } & 0.924 & 0.905 & 0.970 & 15.46 & $B_{1}$ & 7.309 \\
\cline { 2 - 8 } & & & & & $K_{T}(\mathrm{~L} / \mathrm{g})$ & 4.744 \\
\hline
\end{tabular}

Table 2. Kinetic parameters and error deviation data for 4C2NP adsorption onto graphene.

\begin{tabular}{|c|c|c|c|c|c|}
\hline Model & $\mathrm{R}^{2}$ & $\mathrm{R}_{\text {adj. }}^{2}$ & $R m s$ & Parameters & Values \\
\hline \multirow{2}{*}{ Pseudo-first order } & 0.983 & 0.980 & 0.418 & $q_{e, \text { cal }}(\mathrm{mg} / \mathrm{g})$ & 24.974 \\
\cline { 2 - 6 } & & & & $k_{1}\left(\mathrm{~min}^{-1}\right)$ & 0.162 \\
\hline \multirow{2}{*}{ Pseudo-second order } & 0.993 & 0.992 & 0.260 & $q_{e, \text { cal }}(\mathrm{mg} / \mathrm{g})$ & 25.693 \\
\cline { 2 - 6 } & & & & $k_{2}(\mathrm{~g} / \mathrm{mg} \cdot \mathrm{min})$ & 0.0105 \\
\hline
\end{tabular}

(equations 6 and 7, respectively) were also used to determine the best-fit isotherm model. A model with smaller Rms and ARE shows the data accurately [36].

$$
\begin{gathered}
R m s=\frac{1}{n}\left(\sum_{i=1}^{n}\left(q_{i, \exp }-q_{i, c a l}\right)^{2}\right)^{2} \\
A R E=\frac{100}{n} \sum_{i=1}^{n}\left|\frac{q_{i, \exp }-q_{i, c a l}}{q_{i, \exp }}\right|
\end{gathered}
$$

...where $n$ is the number of experimental data points, $q_{i, \exp }$ is the experimental adsorption capacity, and $q_{i, c a l}$ is the theoretically calculated adsorption capacity.

The isotherm parameters and the error functions are listed in Table 1.

By comparing the values of $\mathrm{R}^{2}, \mathrm{R}_{\text {adj. }}^{2}$, and other error functions in Table 1, it is found that the Freundlich model is the most suitable model to satisfactorily describe the studied sorption phenomenon. In this isotherm, if the value of $n$ is below unity, then the adsorption is chemical; otherwise, the adsorption is physical [37]. Thus, in this research the value of 1.624 for $n$ indicates that the adsorption of $4 \mathrm{C} 2 \mathrm{NP}$ onto graphene is a favorable physical process.

\section{Adsorption Kinetic Studies}

The kinetic studies of $4 \mathrm{C} 2 \mathrm{NP}$ adsorption by graphene were investigated by $250 \mathrm{~mL}$ of solution containing 10 $\mathrm{mg} / \mathrm{L} 4 \mathrm{C} 2 \mathrm{NP}$ in the range of 0-60 min. The adsorption kinetic data were described according to the non-linear rate equations of Lagergren's pseudo-first and Ho's pseudo-second order, respectively:

$$
\begin{gathered}
q_{t}=q_{e}\left(1-e^{-k_{1} t}\right) \\
q_{t}=\frac{q_{e}^{2} k_{2} t}{1+k_{2} q_{e} t}
\end{gathered}
$$

...where $k_{1}\left(\mathrm{~min}^{-1}\right)$ and $k_{2}$ (g/mg.min) are the Lagergren and Ho kinetic model rate constants, respectively [38, 39]. In Fig. 7, the plots of adsorption kinetic models are depicted.

Similar to isotherm studies, parameters of these models were determined by non-liner trial and error method using Polymath 6.10 software and are given in Table 2 .

Based on the results (Fig. 7 and Table 2), the pseudosecond-order model has a higher $\mathrm{R}^{2}$ value, lower $R m s$ value, and its calculated equilibrium adsorption amount $\left(q_{e, c a l}\right)$ is closer to the experimental data $\left(q_{e, e x p}=26.737\right.$ $\mathrm{mg} / \mathrm{g})$. On the other hand, the value of $k_{2} q_{e}\left(0.269 \mathrm{~min}^{-1}\right)$ indicates that $4 \mathrm{C} 2 \mathrm{NP}$ adsorption onto graphene is a fast

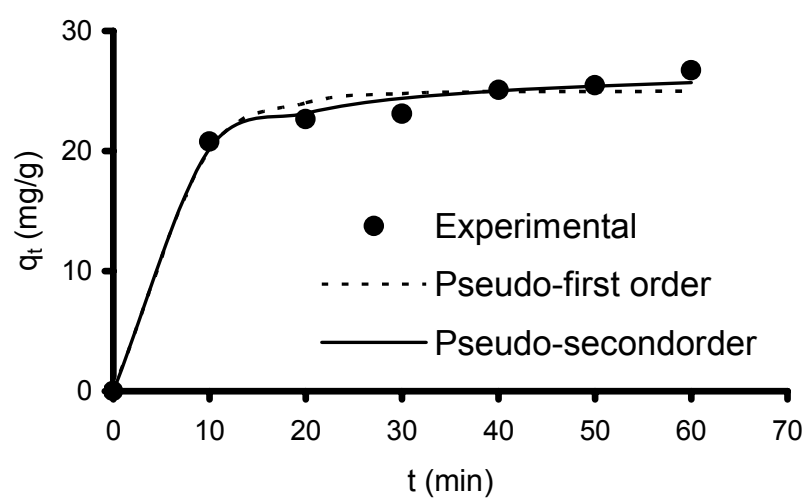

Fig. 7. Plots of non-linear adsorption kinetic models $\left([4 \mathrm{C} 2 \mathrm{NP}]_{0}=10 \mathrm{mg} / \mathrm{L}\right.$, graphene dose $\left.=0.2 \mathrm{~g} / \mathrm{L}, \mathrm{pH}=4.5, \mathrm{~T}=298 \mathrm{~K}\right)$. 
Table 3. Thermodynamic parameters for 4C2NP adsorption onto graphen.

\begin{tabular}{|c|c|c|c|}
\hline $\mathrm{T}(\mathrm{K})$ & $\Delta \mathrm{G}^{\circ}(\mathrm{kJ} / \mathrm{mol})$ & $\Delta \mathrm{H}^{\circ}(\mathrm{kJ} / \mathrm{mol})$ & $\Delta \mathrm{S}^{\circ}(\mathrm{J} / \mathrm{mol} . \mathrm{K})$ \\
\hline 298 & -4.475 & -34.95 & -102.195 \\
\hline 308 & -3.397 & & \\
\hline 318 & -2.251 & & \\
\hline 328 & -1.523 & & \\
\hline
\end{tabular}

process. A similar phenomenon has been observed in adsorption of bisphenol by graphene [40].

\section{Adsorption Thermodynamic Studies}

Thermodynamic studies were performed in four different temperatures, at an initial 4C2NP concentration of 10 $\mathrm{mg} / \mathrm{L}$. Various thermodynamic parameters (standard Gibbs free energy, standard enthalpy, and entropy) were calculated by equations (10-12):

$$
\begin{gathered}
\Delta G^{o}=-R T \operatorname{Ln} K_{C} \\
K_{C}=\frac{q_{e}}{C_{e}} \\
L n K_{C}=-\frac{\Delta H^{o}}{R}\left(\frac{1}{T}\right)+\frac{\Delta S^{o}}{R}
\end{gathered}
$$

...where $K_{C}$ is the equilibrium constant, $T$ is the absolute temperature $(\mathrm{K})$, and $R$ is the universal gas constant (8.314 $\mathrm{J} / \mathrm{mol} \cdot \mathrm{K})[41] . \Delta H^{\mathrm{o}}$ and $\Delta S^{\mathrm{o}}$ were calculated from the slope and intercept of the plot of $\operatorname{Ln} K_{C}$ vs. $1 / T$ using equation 12 (Fig. 8).

According to the results (Table 3 ), negative values of $\Delta G^{\mathrm{o}}$ indicate the spontaneity of the adsorption process. The decrease in $\Delta G^{\mathrm{o}}$ with the decrease of temperature reveals more efficient adsorption at lower temperature. The negative $\Delta H^{\circ}$ value confirms the exothermic nature of the adsorption, which is also supported by the decline in the adsorption capacity of $4 \mathrm{C} 2 \mathrm{NP}$ with the increase in temper-

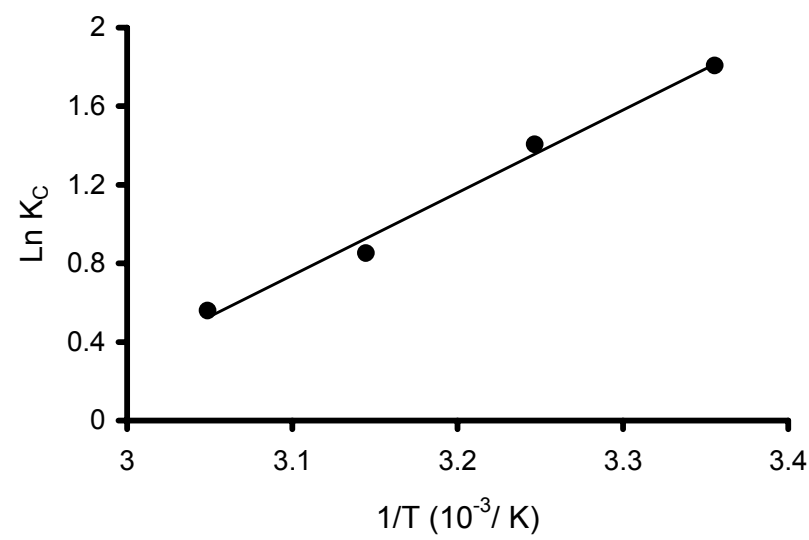

Fig. 8. Plot of $L n K_{C}$ vs. $1 / T\left([4 \mathrm{C} 2 \mathrm{NP}]_{0}=10 \mathrm{mg} / \mathrm{L}\right.$, graphene dose $=0.2 \mathrm{~g} / \mathrm{L}, \mathrm{pH}=4.5$ ). ature. The negative value of $\Delta S^{\mathrm{o}}$ reflects a decrease in freedom degree of the adsorbed species.

\section{Conclusions}

The findings demonstrated that the adsorption of 4C2NP by graphene increased rapidly in the first $10 \mathrm{~min}$ and then achieved equilibrium gradually at about one hour. The adsorption capacity of graphene increased by decreasing $\mathrm{pH}$, temperature, and adsorbent dosage, and increasing the 4C2NP initial concentration. Adsorption isotherm and kinetic studies showed that the Freundlich isotherm equation and pseudo-second-order kinetic model provided the best correlation of the adsorption data. The negative sign of $\Delta \mathrm{G}^{\mathrm{o}}$ and $\Delta \mathrm{H}^{\mathrm{o}}$ indicates that the adsorption process is spontaneous and exothermic. In conclusion, adsorption by the graphene process is an appropriate method for reducing 4C2NP from aqueous solutions.

\section{Acknowledgements}

The authors would like to thank the East Azarbaijan Science and Research Branch of Islamic Azad University for financial support of this research, which is based on a research project contract.

\section{References}

1. DURSUN A. Y., TEPE O. Internal mass transfer effect on biodegradation of phenol by Ca-alginate immobilized Ralstonia eutropha. J. Hazard. Mater. 126, (1-3), 105, 2005.

2. SINGH K. P., MALIK A., SINHA S., OJHA P. Liquid-phase adsorption of phenols using activated carbons derived from agricultural waste material. J. Hazard. Mater. 150, (3), 626, 2008.

3. SRIVASTAVA V. C., SWAMY M. M., MALL I. D., PRASAD B., MISHRA I. M. Adsorptive removal of phenol by bagasse fly ash and activated carbon: equilibrium, kinetics and thermodynamics. Colloid. Surface. 272, (1), 89, 2006.

4. CALACE N., NARDI E., PETRONIO B. M., PIETROLETTI M. Adsorption of phenols by paper mill sludge. Environ. Pollut. 118, (3), 315, 2002.

5. FARROKHI M., MESDAGHINIA A., YAZDANBAKHSH A. R., NASSERI S. Characteristics of Fenton's oxidation of 2, 4, 6 trichlorophenol. Iran J. Environ. Healh Sci. Eng. 1, (1), 12, 2004.

6. SARITHA P., APARANA C., HIMABINDU V., ANJANEYULU Y. Advanced oxidation of 4-chloro-2-nitrophenol (4C-2-NP) - A comparative study. J. Hazard. Mater. 149, (3), 609, 2007.

7. MOUSSAVI G., MAHMOUDI M., BARIKBIN B. Biological removal of phenol from strong wastewaters using a novel MSBR. Water Res. 43, (5), 1295, 2009.

8. AGARRY S. E., SOLOMON B. O. Kinetics of batch microbial degradation of phenols by indigenous Pseudomonas fluorescence. Int. J. Environ. Sci. Tech. 5, (2), 223, 2008.

9. BENITEZ F. J., BELTRAN-HEREDIA J., ACERO J. L., RUBIO F. J. Rate constants for the reactions of ozone with chlorophenols in aqueous solutions. J. Hazard. Mater. B 79, (3), 271, 2000. 
10. GHARBANI P., KHOSRAVI M., TABATABAII S. M., ZARE K., DASTMALCHI S., MEHRIZAD A. Degradation of trace aqueous 4-chloro-2-nitrophenol occurring in pharmaceutical industrial wastewater by ozone. Int. J. Environ. Sci. Tech. 7, (2), 377, 2010.

11. HASHIZUME H. Adsorption of some aromatic compounds by a synthetic mesoporous silicate. J. Environ. Sci. Heal. A 39, (10), 615, 2004.

12. ROOSTAEI N., TEZEL F. H. Removal of phenol from aqueous solutions by adsorption. J. Environ. Manage. 70, (2), 157, 2004

13. BIERNAT J. F., MAKUCH B. Sorbents for Preconcentration of Phenols from Polluted Waters. Supramolecular Assistance. Pol. J. Environ. Stud. 9, (2), 71, 2000.

14. GHOLIZADEH A., KERMANI M., GHOLAMI M., FARZADKIA M. Kinetic and isotherm studies of adsorption and biosorption processes in the removal of phenolic compounds from aqueous solutions: comparative study. J. Environ. Healh Sci. Eng. 11, (29), 1, 2013.

15. BANTA F. A., AL-BASHIR B., AL-ASHEH S., HAYAJNEH O. Adsorption of phenol by Bentonite. Environ. Pollut. 107, (3), 391, 2000.

16. MUBARIK S., SAEED A., MEHMOOD Z., IQBAL M. Phenol adsorption by charred sawdust of sheesham (Indian rosewood; Dalbergiasissoo) from single, binary and ternary contaminated solutions. J. Taiwan Inst. Chem. Eng. 43, (6), 926, 2012.

17. KUMAR S., ZAFAR M., PRAJAPATI J. K., KUMAR S., KANNEPALLI S. Modeling studies on simultaneous adsorption of phenol and resorcinol onto granular activated carbon from simulated aqueous solution. J. Hazard. Mater. 185, (1), 287, 2011.

18. MEHRIZAD A., ZARE K., AGHAIE H., DASTMALCHI S. Removal of 4-chloro-2-nitrophenol occurring in drug and pesticide waste by adsorption onto nano-titanium dioxide. Int. J. Environ. Sci. Tech. 9, (2), 355, 2012.

19. MEHRIZAD A., AGHAIE M., GHARBANI P., DASTMALCHI S., MONAJJEMI M., ZARE K. Comparison of 4chloro-2-nitrophenol adsorption on single-walled and multiwalled carbon nanotubes. Iranian J. Environ. Health Sci. Eng. 9, (5), 1, 2012.

20. GEIM A. K., NOVOSELOV K. S. The rise of graphene. Nature Materials 6, 183, 2007.

21. ZHAO G., LI J., WANG X. Kinetic and thermodynamic study of 1-naphthol adsorption from aqueous solution to sulfonated graphene nanosheets. Chem. Eng. J. 173, (1), 185, 2011.

22. CHANG Y. P., REN C. L., QU J. C., CHEN X. G. Preparation and characterization of $\mathrm{Fe}_{3} \mathrm{O}_{4}$ /graphene nanocomposite and Investigation of its adsorption performance for aniline and p-chloroaniline. Appl. Surf. Sci. 261, (15), 504, 2012.

23. DENG X. J., LU L. L., LI H. W., LUO F. The adsorption properties of $\mathrm{Pb}(\mathrm{II})$ and $\mathrm{Cd}(\mathrm{II})$ on functionalized graphene prepared by electrolysis method. J. Hazard. Mater. 183, (13), 923, 2010.

24. ZHU J., WEI S., GU H., RAPOLE S. B., WANG Q., LUO Z., HALDOLAARACHCHIGE N., YOUNG D. P., GUO Z. One-pot synthesis of magnetic graphene nanocomposites decorated with core@double-shell nanoparticles for fast chromium removal. Environ. Sci. Technol. 46, (2), 977, 2012.
25. CAI X., TAN S., LIN M., XIE A., MAI W., ZHANG X., LIN Z., WU T., LIU Y. Synergistic antibacterial brilliant blue/reduced graphene oxide/quaternary phosphonium salt composite with excellent water solubility and specific targeting capability. Langmuir 27, (12), 7828, 2011.

26. GONEN F., SERIN S. Adsorption study on orange peel: Removal of $\mathrm{Ni}(\mathrm{II})$ ions from aqueous solution. Afr. J. Biotechnol. 11, (5), 1250, 2012.

27. WU S., ZHAO X., LI Y., DU Q., SUN J., WANG Y., WANG X., XIA Y., WANG Z., XIA L. Adsorption Properties of Doxorubicin Hydrochloride onto Graphene Oxide: Equilibrium, Kinetic and Thermodynamic Studies. Materials 6, (5), 2026, 2013.

28. ELLIOTT H. A., HUANG C. P. The Adsorption of $\mathrm{Cu}(\mathrm{II})$ Complexes onto Aluminosilicates. Water Res. 15, (7), 849, 1981.

29. LI Y., DU Q., LIU T., SUN J., JIAO Y., XIA Y., XIA L., WANG Z., ZHANG W., WANG K., ZHU H., WU D. Equilibrium, kinetic and thermodynamic studies on the adsorption of phenol onto graphene. Mater. Res. Bull. 47, (8), 1898, 2012.

30. SHAHRYARI Z., SOLTANI G. A., AZADI M. Experimental study of methylene blue adsorption from aqueous solutions onto carbon nano tubes. Int. J. Water Res. Environ. Eng. 2, (2), 16, 2010.

31. MORADI O., AGHAIE M., ZARE K., MONAJJEMI M., AGHAIE $\mathrm{H}$. The study of adsorption characteristics $\mathrm{Cu}^{2+}$ and $\mathrm{Pb}^{2+}$ ions onto PHEMA and P(MMA-HEMA) surfaces from aqueous single solution. J. Hazard. Mater. 170, (2-3), 673, 2009.

32. LANGMUIR I. The constitution and fundamental properties of solids and liquids. J. Am. Chem. Soc. 38, (11), 2221, 1916.

33. FREUNDLICH H. M. F. Uber die adsorption in losungen. Z. Phys. Chem. 57, (A), 385, 1906.

34. TEMKIN M., PYZHEV V. Kinetics of the Synthesis of Ammonia on Promoted Iron Catalysts. J. Phys. Chem. 13, 851, 1940.

35. BEHNAJADY M. A., BIMEGHDAR S. Synthesis of mesoporous $\mathrm{NiO}$ nanoparticles and their application in the adsorption of $\mathrm{Cr}$ (VI). Chem. Eng. J. 239, 105, 2014.

36. ALLEN S. J., GAN Q., MATTHEWS R., JOHNSON P. A. Comparison of optimised isotherm models for basic dye adsorption by kudzu. Bioresource Technol. 88, (2), 143, 2003.

37. WU C. H. Adsorption of reactive dye onto carbon nanotubes: equilibrium, kinetics and thermodynamics. J. Hazard. Mater. 144, (1-2), 93, 2007.

38. LAGERGREN S. Y. Zur theorie der sogenannten adsorption geloster stoffe. K. Seven. Vetenskapsakad. Handl. 24, (4), 1, 1898.

39. HO Y. S., MCKAY G. Pseudo-second order model for sorption processes. Process Biochem. 34, 451, 1999.

40. XU J., WANG L., ZHU Y. Decontamination of Bisphenol A from Aqueous Solution by Graphene Adsorption. Langmuir 28, 8418, 2012.

41. MORADI O., ZARE K., MONAJJEMI M., YARI M., AGHAIE H. The Studies of Equilibrium and Thermodynamic Adsorption of $\mathrm{Pb}$ (II), $\mathrm{Cd}(\mathrm{II})$ and $\mathrm{Cu}$ (II) Ions from Aqueous Solution onto SWCNTs and SWCNT-COOH Surfaces. Fuller. Nanotub. Car. N. 18, 285, 2010. 